\title{
JUSTICE FOR THE MENOPAUSE: A RESEARCH AGENDA
}

\section{NAOMI CAHN*}

\section{Menopause is not a punch line. ${ }^{1}$}

Menopause is defined by its relationship to menstruation - it is the cessation of menstruation. Medical texts identify menopause as part of the cycle of "decay" associated with female reproductive functions; ${ }^{2}$ early menopause is often a dreaded result of various medical treatments and a sign of disfunction.

It turns out that only three types of animals experience menopause: killer whales, short-finned pilot whales, and humans, while other animals can reproduce until death. ${ }^{3}$ Although the precise relationship between evolutionary theory and the physical development of human menopause is still uncertain, scientists and anthropologists suggest that the "grandmother hypothesis" provides a partial explanation: older women, who can no longer produce their own children, ensure their genetic legacy by playing a critical role in helping to feed, raise, and nurture their grandchildren.

\footnotetext{
* Justice Anthony M. Kennedy Distinguished Professor of Law, Nancy L. Buc '69 Research Professor in Democracy and Equity, University of Virginia School of Law. Thanks to Bridget Crawford and Margaret Johnson for their generous comments and encouragement, to Erica Rand and Emily Gold Waldman for their guidance, and to Jolena Zabel for her support and extensive research assistance. This article was prepared for the CJGL Symposium, Are You There Law? It's Me, Menstruation. Thanks to all participants and the Journal editors.

${ }^{1}$ Darcey Steinke, No One Told Me Exactly What to Expect from Menopause. But the Messages I Did Get Were Very Wrong, TIME (June 28, 2019), https://time.com/5616247/menopause-expect-messages/ [https://perma.cc/JCC4-9JDL].

${ }^{2}$ Mathilde Cohen, The Law of Placenta, 31 YAle J.L. \& Feminism 337, 371 (2020). Menopause has resonance with amenorrhea, which may be experienced by those who menstruate; both, however, involve the absence of menstruation. Absence of menstruation, at whatever stage of life, has its own stigma.

${ }^{3}$ Ed Yong, Why Killer Whales (and Humans) Go Through Menopause, The AtLantic (Jan. 12, 2017), https://tinyurl.com/ycbhotcf [https://perma.cc/35T9-XGD8].
} 
The average woman ${ }^{4}$ will spend almost as many years "post-menopause" as they will menstruating, and they may spend four years (or more) experiencing perimenopausal symptoms, the transition time between "normal" menstruation and menopause. But legal issues relating to perimenopause, menopause, and post-menopause are just beginning to surface, prompted by the movement towards menstrual justice, feminist jurisprudence, and developments in the law of aging.

This Essay is an initial effort to catalogue various legal approaches to menopause and to set out areas for further analysis. It briefly explores cultural images of menopause and post-menopausal women, including the ubiquitous hot flashes; analyzes potential legal claims for menopausal justice; and suggests the interrelationship between such approaches and social attitudes towards menopause. It suggests that "normalizing" menopause - acknowledging its realities - is one means for removing the associated stigma and "disabilities" 5 and might result in reinterpreting existing laws and guiding future legal reforms. ${ }^{6}$

\section{Menopause Culture}

In late 2020, an article in Glamour magazine tartly noted that "the way we talk about [menopause] (or rather, don't talk about it) in our society would make you think it's a

\footnotetext{
${ }^{4}$ Not all women menstruate, and not all who menstruate are women. Margaret E. Johnson, Emily Gold Waldman, \& Bridget J. Crawford, Title IX \& Menstruation, 43 HARV. J. L. \& GENDER 225, 268 (2020). Throughout this Article, I attempt to use inclusive language that recognizes this reality. Nevertheless, most of the stereotypes and medical terminology discussed in the article use the term "woman," so this Essay will sometimes use that term, with an appreciation of the risks of essentialism and also of the risks of identifying individuals solely with reference to their biology. See Brittney McNamara, Period Activist Cass Clemmer Responds to Hate After Posting Period Photo, Teen Vogue (Aug. 2, 2017), https://www.teenvogue.com/story/period-activist-cass-clemmer-what-its-like-to-get-periods-whiletransgender [https://perma.cc/NL43-HK7A] (addressing menstruation and transgender).

${ }^{5}$ Using the term "disability" raises more issues than it answers. As Jenna Lauter notes, it could "mean that normalizing menopause might remove the actual disabilities menopausal women experience [o]r that it could reduce societal perceptions that menopause produces disability, [o]r alternatively that normalizing menopause could prompt society to better accommodate menopause to make it less disabling." And there are different models of disability and the law, including the medical and social models, as well as "the idea that there is no such thing as impairment but there are instead just neutral traits turned to disadvantage by the environment." Elizabeth Emens, Disability Admin: The Invisible Costs of Being Disabled, 105 MinN. L. Rev. 2329, 2339 (2021).
}

${ }^{6}$ See Bridget J. Crawford, Margaret E. Johnson, Marcy L. Karin, Laura Strausfeld, \& Emily Gold Waldman, The Ground on Which We All Stand: A Conversation About Menstrual Equity Law and Activism, 26 MicH. J. GENDER \& L. 341, 386 (2019). 
dirty word or something to be ashamed of - rather than a natural part of the aging process for women."7

It wasn't until the early eighteenth century that menopause began to be viewed as a medical disorder, although the cessation of menstruation was not a new concept. ${ }^{8}$ But it was the distinctive naming of the experience, and its framing as a disorder that first appeared in medical journals around that time.

Since then, much of the focus on menopause has been on curing clinical symptoms, ranging from hot flashes to "vaginal and vulvar atrophy" to the multiple other potential symptoms of perimenopause and menopause ${ }^{10}$ and helping to ensure that menopause "was [not] the end of real life." "While menstruating women may face the cultural trope of being "impure" and "dirty, ${ }^{12}$ those experiencing menopause face intersectional stereotypes based on both gender and aging. Efforts to "control" menopause and its aftermath through hormone replacement therapy (HRT) became popular after gynecologist Robert Wilson published a best-selling book, Feminine Forever, claiming that menopause was a disease that resulted from an estrogen deficiency and could be

\footnotetext{
${ }^{7} 10$ Celebrities Who have Spoken Out About Menopause, Glamour (Oct. 5, 2020), https://www.glamour.com/gallery/celebrities-who-have-spoken-out-aboutmenopause\#: : text=Gwyneth\%20Paltrow,The $\% 20$ queen $\% 20$ of\&text $=\%$ E2\%80\%9CI\%20think $\% 20$ when $\% 20$ you $\% 20$ get,needs $\% 20$ a $\% 20 \mathrm{bit} \% 20$ of $\% 20$ rebranding [https://perma.cc/2HCW-RDBL].

${ }^{8}$ See Susan Mattern, The Slow Moon Climbs: The Science, History, and Meaning Of Menopause 27071 (2019); Susan Mattern, What if We Didn't Dread Menopause?, https://www.nytimes.com/2019/09/12/opinion/sunday/menopause-symptoms.html [https://perma.cc/6R734H6T].

${ }^{9}$ Introduction to Menopause, JoHns HopKIns Medicine, https://www.hopkinsmedicine.org/health/conditions-and-diseases/introduction-tomenopause\#: : :text=Hot\%20flashes\%20or\%20flushes\%20are,for\%202\%20years\%20or\%20less [https://perma.cc/27VN-VTDW].

${ }^{10}$ Symptoms, GEN M, https://gen-m.com/symptoms/ [https://perma.cc/E9TR-EZCT].

${ }^{11}$ Gail Collins, No Stopping Us Now: The Adventures of Older Women in American History 177 (2020).

12 Johnson et al., supra note 4, at 15.
} 
treated with estrogen replacement therapy: the promise was that women would never experience the effects of aging. ${ }^{13}$

While HRT can be an effective treatment for menopause symptoms, not only might it - ironically - cause monthly bleeding, ${ }^{14}$ it also is still marketed as a pseudo-youth elixir. ${ }^{15}$ The use of HRT preys on fears of aging, and raises questions of what counts as a legitimate "medical" issue for which treatment is needed.

Of course, notwithstanding the medical and cultural descriptions, individuals do not necessarily experience menopause as a negative disorder. ${ }^{16}$ From a medical perspective, at least some menopausal symptoms appear to be culturally-dependent and responsive to psychological interventions. ${ }^{17}$ And symptoms vary, based on numerous factors. ${ }^{18}$

Culturally, women themselves have recognized that the years after childbearing might finally free them to experience "more comfort and satisfaction." 19 Indeed, at a time

\footnotetext{
${ }^{13}$ Judith A. Houck, "What Do These Women Want?": Feminist Responses to "Feminine Forever", 19631980, 77 Bull. Hist. Med. 103, 104 (2003).
}

${ }^{14}$ Menopause Hormone Therapy: Does it Cause Vaginal Bleeding?, MAYo ClinIC (Dec. 02, 2020), https://www.mayoclinic.org/diseases-conditions/menopause/expert-answers/hormone-replacementtherapy/faq-20058499 [https://perma.cc/JEF3-6NN6]; Side Effects: Hormone Replacement Therapy, NHS (Sept. 9, 2019), https://www.nhs.uk/conditions/hormone-replacement-therapy-hrt/side-effects/ [https://perma.cc/2N6P-WFWN].

${ }^{15}$ E.g., Which Hormones Make You Look Younger?, DFRW ANTI-AgING WeLlnESS Centers (Jan. 24, 2020), https://www.dfwantiagingwellness.com/2020/01/24/which-hormones-make-you-look-younger/ [https://perma.cc/F7XJ-GNAX] ("Did you know that your hormone levels are evident on your face? It's a little-known fact, but it's true, and no amount of cosmetic treatments can cover up the fact that your hormone levels affect how young you look and feel. For this reason, hormone replacement therapy is becoming a popular treatment for tackling symptoms of age.").

${ }^{16}$ Julia Prague, Life After Reproduction, 574 Nature 34, 34 (2019).

${ }^{17}$ MATteRN, supra note 8, at 344 ("complexities in measuring and talking about hot flashes are one reason it has been so hard to generalize about them"). But see Myra S. Hunter, Menopause and Midlife: Psychosocial Perspectives and Interventions, in Routledge InT'L HANDBOOK OF WOMEN's SeXuAl AND ReProd. Health 83 (Jane M. Ussher et al. eds., 2019); Claire Hardy et al., Self-Help Cognitive Behaviour Therapy for Working Women with Problematic Hot Flushes and Night Sweats (MENOS@Work): A Multicenter Randomized Controlled Trial, 25 Menopause 508 (2018).

${ }^{18}$ See, e.g., Samar R. El Khoudary, The Menopause Transition and Women's Health at Midlife: A Progress Report from the Study of Women's Health Across the Nation (SWAN), 26 MENOPAuSE 1213 (2019).

${ }^{19}$ Collins, supra note 11, at 11-12 (quoting the eighteenth-century diary of Elizabeth Drinker). 
with little birth control and when dominant cultural tropes confined women to a separate sphere, it is not surprising that Elizabeth Cady Stanton predicted that she would not reach her prime until age fifty. ${ }^{20}$ It is a time of "ungendering," an "opportunity [] to finally slip outside the brutal binary system" of gender. ${ }^{21}$

Nonetheless, the negative stereotype persists, and menopause remains simultaneously the subject of scorn and neglect. Recently, an attorney disparagingly commented that opposing counsel might be too warm in a room because of menopause. ${ }^{22}$ Women report difficulties with handling menopause at work, ${ }^{23}$ ranging from the temperature in the office to managing symptoms to harassment ${ }^{24}$ untreated hot flashes result not just in a loss of productivity at work but also higher health claims ${ }^{25}$ and a group calling itself the Red Hot Mamas - the "leading provider of menopause education and support programs" ${ }^{26}$ - even offers tips on how to handle symptoms, such as erratic periods at the office. ${ }^{27}$ The femtech industry, which has focused on menstruation and fertility, is just

\footnotetext{
${ }^{20} I d$. at 46.
}

${ }^{21}$ Darcey Steinke, Flash Count Diary: Menopause and the Vindication of Natural Life 81 (2019); see Erica Rand, The Small Book of Hip Checks: On QueEr Gender, Race, and Writing (Writing MATTERs!) 111-12 (2020) (describing how menopause made her feel "degendered," and she "could situating the mourning of [her] curvy hips within the erotics of butch/femme").

22 "You're not getting menopause, I hope," quote. Cruz-Aponte v. Caribbean Petroleum Corp., 123 F. Supp. 3d 276, 278-79 (D.P.R. 2015).

${ }^{23}$ Claire Hardy et al., Tackling the Taboo: Talking Menopause-Related Problems at Work, 12 INT'L J. OF Workplace Health Mgmt. 28 (2019).

${ }^{24}$ E.g., Megan Reitz, Marina Bolton, \& Kira Emslie, Is Menopause a Taboo in Your Organization?, HARV. Bus. REV. (Feb. 4, 2020) https://hbr.org/2020/02/is-menopause-a-taboo-in-your-organization [https://perma.cc/JP8V-675K ] ("Some women report being ridiculed, harassed, or stereotyped for being menopausal.").

${ }^{25}$ Sheryl Kraft, Menopause in the Workplace: How Women Can Cope, NeXt Avenue (Nov. 29, 2019), https://www.nextavenue.org/menopause-workplace-women-cope/ [https://perma.cc/UR7G-GKX3].

${ }^{26}$ Red Hot Mamas, About Us, Red Hot Mamas (June 7, 2014), https://redhotmamas.org/about-us/ [https://perma.cc/7X8E-NB4Y].

${ }^{27}$ Red Hot Mamas, 10 Expert Tips - How to Deal with Menopause Symptoms at Work, ReD Hot MAMAS (Dec. 19, 2014), https://redhotmamas.org/10-expert-tips-how-to-deal-with-menopause-symptoms-at-work/ [https://perma.cc/H2GM-P8L4] ("About half of employed women between the ages of 45 and 65 say that managing menopausal symptoms on the job is somewhat or extremely difficult."). Indeed: 
beginning to turn to menopause $;^{28}$ while there may be data privacy benefits to not being the subject of femtech, this also suggests menopausal women are not worthy of commodification.

\section{Legal Theories and Potential Claims}

At one point, menopausal women were explicitly treated differently, such as through insurance denials, because menopause allegedly "disrupted all sorts of physical functions and created nervousness." ${ }^{29}$ By using the "menopause defense," a party could diminish the harms experienced by menopausal plaintiffs by attributing the women's damages to menopause, thereby providing a potential basis to limit relief. ${ }^{30}$ Such allegations might be made against any woman over the age of thirty-five, covering a broader range of women than those actually undergoing menopause..$^{31}$ Indeed, airlines attempted to justify age limits of 32 on flight attendants by explaining "that the performance of the stewardess' job requires enthusiasm which is lost with age. . . that women between the ages of 38 and 50 undergo changes of body, personality and emotional reactions, which would interfere with their performance of the stewardess' job," and that, once they reach their midthirties, women thereafter undergo changes associated with the menopause which $[\ldots]$

[w]arm environments, stress, lack of access to cold drinking water and certain kinds of required work wear or uniforms can all make the experience of hot flushes worse. High levels of workplace noise may mean difficulties with focus and attention are exacerbated. Equally, working with younger colleagues, men and clients/customers/students/end users could heighten a menopausal woman's anxiety around her self-presentation. Furthermore, physically demanding work or insufficient toilet facilities can make heavy and/or erratic periods even harder to manage.

${ }^{28}$ Jo Brewis, The Health and Socioeconomic Impact on Menopausal Women of Working from Home, 27 Case Reps. In Women's Health (2020); Bethany A. Corbin, Digital Micro-Aggressions and Discrimination: Femtech and the "Othering" of Women, 44 Nova L. Rev. 337, 343 n.50 (2020); Zara Stone, Femtech Startups Are Finally Innovating for Menopause, ElEMENTAL (Apr. 29, 2019), $\mathrm{https}$ ://elemental.medium.com/femtech-startups-are-finally-innovating-for-menopause-5d16bd1 fdb3d [https://perma.cc/KG3M-5EQS].

${ }^{29}$ Valarie K. Blake, Ensuring an Underclass: Stigma in Insurance, 41 CARDOZO L. REV. 1441, 1469 (2020).

${ }^{30}$ Phyllis T. Bookspan \& Maxine Kline, On Mirrors and Gavels: A Chronicle of How Menopause Was Used as a Legal Defense Against Women, 32 IND. L. REv. 1267, 1288-90 (1999).

${ }^{31} I d$. They write that following a 1916 opinion establishing menopause as a defense to mitigate personal injury damages, "[a]s long as a woman was thirty-five or over, efforts were made to blame whatever complaint she had on menopause." Id. at 1289-90. Successful defendants would "cast female plaintiffs in a negative light and try to persuade courts and juries that the woman suing them was already a damaged person and thus entitled to little or no recovery." Id. at 1272. 
would interfere with their satisfactory performance of the stewardess job., ${ }^{, 32}$ In 1999, a law review article observed that menopause had been invoked "in over fifty reported appellate decisions," pertaining to (1) negligence and personal injury, (2) divorce, (3) worker's compensation, and even (4) product liability cases. ${ }^{33}$

That explicit, almost-blanket discrimination against menopausal women (or women who might be menopausal) based solely on age is now subject to the Age Discrimination in Employment Act (at least for age 40 and over), and the differential treatment has instead assumed alternative forms, a parallel development to other forms of sex-based discrimination. This section provides a brief overview of various legal issues affected by menopause, including an alphabet of antidiscrimination provisions.

\section{A. The Pregnancy Discrimination Act}

One of the most salient menopause-related legal issues is whether the Pregnancy Discrimination Act (PDA) covers menopause-related discrimination. The PDA covers pregnancy and related conditions; this has been extended to include lactation, abortion, and under specific circumstances, use of contraception and infertility treatments. ${ }^{34}$ With respect to menopause, however, there is little reported case law. In Coleman v. Bobby Dodd Inst., Inc., a lower court held that firing a woman who had soiled company property twice because she was pre-menopausal and experiencing heavy periods, did not constitute sex discrimination under the PDA. ${ }^{35}$ The case was settled and did not foreclose such claims in the future; it instead suggested a means for future plaintiffs to proceed by engaging in a comparative showing with similar medical conditions affecting both sexes,

32 Termination or Reassignment of Airline Stewardess After Reaching 32 Years of Age Held Unlawful Sex Discrimination, Empl. Prac. Guide P 6001 (C.C.H.), 1968 WL 201597; see Toni Scott Reed, Flight Attendant Furies: Is Title VII Really the Solution to Hiring Policy Problems, 58 J. AIR L. \& COM. 267, 307 (1992) (providing further details about the age-based limitations for women).

${ }^{33}$ Bookspan \& Kline, supra note 30, at 1287-88.

34 The U.S. Equal Employment Opportunity Commission's guidance on the PDA defines its coverage to prohibit discrimination based on current pregnancy, past pregnancy, potential or intended pregnancy (including infertility treatments and contraceptive use), and medical conditions related to pregnancy or childbirth, including lactation and abortion. U.S. EQUAL EMP. OPPORTUNITY COMM'N, EEOC-CVG-2015-1, ENForcement Guidance on Pregnancy Discrimination AND Related Issues (2015). Menstruation is not mentioned. Id.

${ }^{35}$ Coleman v. Bobby Dodd Inst., Inc., No. 4:17-CV-29, 2017 WL 2486080, at *2 (M.D. Ga. June 8, 2017). See Margaret E. Johnson, Menstrual Justice, 53 U.C. DAvis L. REv. 1, 32 (2019); Jennifer Weiss-Wolf, U.S. Policymaking to Address Menstruation: Advancing an Equity Agenda, 25 WM. \& MARY J. RACE, GENDER \& Soc. Just. 493, 517 (2019). 
and in fact provided the basis for a later case of discrimination by a menstruating woman. $^{36}$

Indeed, as the Georgia ACLU argued in Coleman, "the PDA applies not only to pregnancy itself, but also to sex-linked conditions linked to women's reproductive capacity, such as the ability to become pregnant, infertility, and regularity of the menstrual cycle. . . Premenopause and its symptoms are, of course, included among such sex-linked conditions." 37 Accordingly, a broad interpretation of the PDA might include menopause-related discrimination. Nonetheless, no U.S. court has yet done so.

\section{B. The Americans with Disabilities Act}

An alternative legal remedy might rest in the Americans with Disabilities Act (ADA), although the concept of menopause as a "disability" raises critical jurisprudential and pragmatic issues. Courts use a three-part test to determine whether a person has a disability under the ADA: there must be a (1) "physical or mental impairment;" (2) affecting a "major life activity," that (3) "substantially limit[s]" that activity. ${ }^{38}$ The Supreme Court has held that reproduction constitutes such a "major life activity,"39 finding that the statute covered a woman's HIV status as a physical impairment that substantially impaired reproduction - a major life event. ${ }^{40}$ Thus, pregnancy-related issues can qualify as physical or mental impairments. ${ }^{41}$

\footnotetext{
${ }^{36}$ Betancourt v. Margaritaville Hollywood, Beach Resort, L.P., No. 18-CV-62538, 2019 WL 2119611, at *4 (S.D. Fla. Mar. 29, 2019).

${ }^{37}$ Initial Brief of Plaintiff-Appellant at 19, Coleman v. Bobby Dodd Inst., Inc., 2017 WL 6762403 (11th Cir. Aug. 14, 2017) (No. 17-13023) (case dismissed after settlement). See Brooks Land, Battle of the Sexes: Title VII's Failure to Protect Women from Discrimination Against Sex-Linked Conditions, 53 GA. L. REv. 1185, 1209 (2019).

${ }^{38}$ See Bragdon v. Abbott, 524 U.S. 624, 630-31 (1998) (applying the three-factor test used by lower courts); see also Sarah Lynn Oquist, Reproduction Constitutes a "Major Life Activity" Under the ADA: Implications of the Supreme Court's Decision in Bragdon v. Abbott, 32 Creighton L. Rev. 1357, 1358 (1999).

${ }^{39}$ Bragdon, 524 U.S. at 638.

${ }^{40}$ Bragdon, 524 U.S. at 641 ("Respondent's HIV infection is a physical impairment which substantially limits a major life activity, as the ADA defines it.").

${ }^{41}$ Americans with Disabilities: Practice \& Compliance Manual, $\S 7: 84$. For a critique of this holding that also briefly addresses whether menopause should fall under this category, see Amanda C. Steele, Bragdon v. Abbott: Stretching the Statutory Limits of the Americans with Disabilities Act, 44 S.D. L. Rev. 783, 786-87, n.17 (1999).
} 
Menopause, however, is different. In McGraw v. Sears, Roebuck \& Co. ${ }^{42}$ the district court distinguished menopause from loss or impairment of reproduction due to an illness (e.g., HIV), finding it an "entirely normal consequence of human aging." ${ }^{43}$ Since McGraw, the few analogous cases agree that menopause (at least on its own) does not qualify as a disability ${ }^{44}$ Courts have acknowledged that complications attendant to menopause might cause substantial limitations on a major life activity. ${ }^{45}$

By contrast, when menopause is "not" naturally occurring, courts have been willing to consider ADA coverage. For example, in Mullen v. New Balance Athletics, thirty-fiveyear-old Mullen went into menopause after a hysterectomy to address severe ovarian cysts. ${ }^{46}$ Following an "outburst," which she alleged was caused by her symptoms of menopause, Mullen was pressured into resigning from her job. ${ }^{47}$ The court held that a "reasonable jury could find that an impairment to the endocrine system sufficient to place the plaintiff abruptly into menopause at the age of 35 constituted a substantial limitation." ${ }^{48}$ The court emphasized the plaintiff's age and the fact that the menopausal symptoms were caused by a hysterectomy. ${ }^{49}$ Thus, while framing Mullen's impairment as symptoms of menopause, the court differentiated Mullen's situation from that of a person in menopause due to regular aging.

\footnotetext{
${ }^{42}$ McGraw v. Sears, Roebuck \& Co., 21 F. Supp. 2d 1017 (D. Minn. 1998); see Oquist, supra note 38, at $1401-02$.

${ }^{43}$ McGraw, 21 F. Supp. 2d at 1021; see Oquist, supra note 38, at 1401-02.

${ }^{44}$ E.g., Sipple v. Crossmark, Inc., No. 2:10-CV-00570-MCE-KJM, 2012 WL 2798791, at *5 (E.D. Cal. July 9, 2012) ("no case law suggests that menopause qualifies as a disability either under [California law] or the ADA."). The plaintiff was a menopausal woman experiencing hot flashes, among other symptoms, and sought an exception from her employer's dress code. Id. at *1-2.
}

${ }^{45}$ Klein v. Florida Dep't of Child. and Fams. Servs., 34 F. Supp. 2d 1367, 1372 (S.D. Fla. 1998) (decided shortly after Bragdon). See Helen L. Norton et al., Coverage of Reproductive Technologies Under EmployerSponsored Health Care Plans: Proceedings of the 2004 Annual Meeting, Association of American Law Schools, Sections on Employee Benefits and Employment Discrimination, 8 EMP. RTs. \& EMP. PoL'Y J. 523, 530 (2004) (remarks of Professor Norton that menopause is not an "impairment").

${ }^{46}$ Mullen v. New Balance Athletics, Inc., No. 1:17-cv-194-NT, 2019 WL 958370, at*1, *6 (Feb. 27, 2019).

${ }^{47} I d$. at $* 2-3$.

${ }^{48} I d$. at *6 (emphasis added).

${ }^{49}$ E.g., id. (citing Hubbard v. Day \& Zimmermann Hawthorne Corp., No. 3:12-CV-00681-MMD, 2015 WL 1281629 , at *4-5 (D. Nev. Mar. 20, 2015)). 
"Normal" menopause has thus not yet been treated as a disability under the ADA. While that serves as a recognition that menopause is part of the ordinary course of a woman's life experience, and may be the appropriate legal outcome, that does not preclude particularly severe menopausal symptoms from being covered.

\section{Other Potential Legal Claims}

The Age Discrimination in Employment Act covers differential treatment for anyone age forty and over and provides a potential source for claims based on either differential treatment or impact. It has not yet been tested with respect to menopause. The Family and Medical Leave Act provides leave for a woman's own health condition, so "normal" menopause probably does not rise to the level of a serious health condition that could provide the basis for leave.

Other aspects of menopause-related issues concern health law, such as the availability of assisted reproductive treatments to post-menopausal women, or the inclusion or exclusion of older women in medical trials. ${ }^{50}$

\section{Moving Forward}

Menopause is both exceptionalized, with its association with irrational women experiencing hot flashes and the unwritten message that "your usefulness is over," unexceptional, a normal part of the aging process. Cultural images of menopause invariably affect the experience. Legal approaches are nascent and, to some extent, they resonate with the decades-old dilemma of sameness and difference, powerfully articulated in the context of pregnancy; that is, given that menopause is a normal part of the aging process, should it be treated without any special protection (like any other condition) or does it merit special protections. Moreover, determining when discrimination is based on age or menopausal stereotypes underscores the challenges of intersectional legal claims.

Other countries may provide some guidance for the menopausal equity movement. For example, in England, researchers, advocates, and attorneys are engaging in a conversation about menopause, its impact on individuals, and potential discrimination as

\footnotetext{
${ }^{50}$ Given the introductory nature of this Essay, it does not provide further exploration of health law and Title VII; such analysis is forthcoming in Naomi Cahn, Bridget Crawford, \& Emily Waldman, Menopause: Moving the Law Forward (unpublished Essay 2021).

${ }^{51}$ Steinke, supra note 1.
} 
a result of that impact. ${ }^{52}$ Menopause is generally covered under the prohibition against age, sex, and disability discrimination in British law and also extends to working conditions of people experiencing menopausal symptoms. ${ }^{53}$ British members of parliament have also advocated for businesses to adopt menopause policies analogous to maternity policies because menopause "exacts a hefty personal and professional toll." 54 They have even proposed enacting legislation requiring such policies be put in place..$^{55}$

Resources for UK employers, including advice from law firms, describe the impact of menopause on work, noting that the failure to treat menopause like other disabilities constitutes discrimination. ${ }^{56}$ The British government notes the importance of health and safety checks, such as for "temperature and ventilation," as well as training for managers in the workplace. ${ }^{57}$ This is in contrast to cases in the U.S., which suggest that menopause caused early by a medical condition may merit protection where other symptoms would not. $^{58}$

\footnotetext{
${ }^{52}$ See, e.g., Carol Atikson, Fiona Carmichael \& Joanne Duberley, Menopause Discrimination is a Real Thing - This Is How Employers Can Help, THE CONVERSATION (Jan. 14, 2019 at 8:28 AM EST), https://theconversation.com/menopause-discrimination-is-a-real-thing-this-is-how-employers-can-help108641 [https://perma.cc/5C33-TFTE]; Sarah Bosely \& Hilary Osborne, Workplaces Must Protect Women Going Through Menopause, Say MPs, The GuARDian (Aug. 25, 2019 at 11:00 AM EDT), https://www.theguardian.com/society/2019/aug/25/mandatory-workplace-menopause-policies-uk [https://perma.cc/F4ND-JEY7]; see also Hilary Weaver, Menopause Discrimination Affects Millions of American Women, SuPERMAJORITY News (Feb. 7, 2020), https://supermajority.com/news/educationfund/menopause-discrimination-affects-millions-of-american-women/ [https://perma.cc/82SP-E5A6] (citing UK researchers as leaders in addressing menopause discrimination).
}

${ }^{53}$ Employment Law and Menopause, HeNPICKed (Aug. 24, 2020), https://menopauseintheworkplace.co.uk/employment-law/menopause-and-employment-law/ [https://perma.cc/54KS-ZYY3].

${ }^{54}$ Boseley \& Osborne, supra note 52.

${ }^{55} \mathrm{Id}$.

${ }^{56}$ E.g. Menopause At Work, ACAS, https://archive.acas.org.uk/menopause [https://perma.cc/6N2K-3GEK]; United Kingdom: Menopause, A Business Issue (Sept. 30, 2020), https://www.bakermckenzie.com/en/insight/publications/2020/09/uk-menopause-business-issue [https://perma.cc/U2HX-F8GW].

${ }^{57}$ Menopause at Work, supra note 56.

${ }^{58}$ Compare McGraw, 21 F. Supp. 2d at 1021 with Klein, 34 F. Supp. 2d at 1372 and Merchant v. BT PLC (discussed in United Kingdom: Menopause, A Business Issue, supra n. 56); Viola Lloyd, Failure to Address Menopause Amounted to Sex Discrimination, THE HR DiR. (Apr. 18, 2012),

https://www.thehrdirector.com/legal-updates/legal-updates-2012/failure-to-address-menopause-amounted-to- 
In short, the UK has both more expansive legal protection for people experiencing menopause and an apparently more rigorous discourse on the issue.

Even if the ADA might provide limited protection (casting menopause as a disability, however, raises complex jurisprudential questions), it would be more comprehensive to amend the PDA "to prohibit discrimination against all conditions related to a woman's reproductive capacity," ${ }^{59}$ thereby ensuring inclusion of both menstruation and menopause. In the absence of such an amendment, Title VII may provide a remedy, particularly where there is direct evidence.$^{60}$ Other options include working with, or within, the movement for menstrual justice. Menopausal equity could then be treated as one critical component in ensuring that involuntary biological process like menstruation (as well as its absence) do not impair full participation in all aspects of public and private life. Or, menopausal equity might instead result in separate, albeit overlapping advocacy, part of the growing movement to reclaim "older age" as a positive time of growth and creativity, rewriting the narrative to eradicate stigma. Ultimately, any movement for menopausal equity will need to be part of a larger agenda that also includes changing cultural attitudes of stigma and shame.

The concept of menopause justice is just gaining traction, and this Essay is only the beginning of future cultural and legal conversations.

\footnotetext{
sex-discrimination/ [https://perma.cc/G3M6-H5S9]; and Emma Clark, Menopause: The Last Taboo in the Workplace?, ThOMsOn Reuters EMP. \& Discrimination Blog (Jul. 4, 2018), http://employmentblog.practicallaw.com/menopause-the-last-taboo-in-the-workplace/ [https://perma.cc/NZ8M-E2EP].

${ }^{59}$ Land, supra note 37, at 1214.

${ }^{60}$ See, e.g., Johnson, Menstrual Justice, supra note 35, at 29-30.
} 